\title{
PENGARUH KECERDASAN EMOSIONAL DAN LINGKUNGAN KERJA KARYAWAN DI CV. BALI COCO FIBER JEMBRANA
}

\author{
M. Pasolo ${ }^{1}$, P.G Parma ${ }^{2}$ \\ 1,2Jurusan Manajemen, Universitas Pendidikan Ganesha, Singaraja \\ email: nanapasolo9@gmail.com, parma1708@yahoo.com,
}

\begin{abstract}
Abstrak
Penelitian ini bertujuan untuk menguji pengaruh: (1) Kecerdasan emosional dan lingkungan kerja terhadap kinerja karyawan, (2) Kecerdasan emosional terhadap Kinerja karyawan, (3) Lingkungan kerja terhadap Kinerja karyawan. Penelitian ini menggunakan desain penelitian kuantitatif kausal, subjek dalam penelitian ini adalah seluruh karyawan yang ada di CV Bali Coco Fiber Jembrana, populasi dalam penelitian ini berjumlah 48 karyawan. Data yang di kumpulkan dengan teknik wawancara terstruktur dan kuesioner. Hasil penelitian analisin regresi linear berganda menunjukan bahwa secara simultan. (1) Kecerdasan emosional berpengaruh positif dan signifikan terhadap Lingkungankerja,(2) Kecerdasan emosional berpengaruh positif dan signifikan terhadap Kinerja karyawan (3) Lingkungan kerja berpengaruh positif dan signifikan terhadap Kinerja karyawan di CV Bali Coco Fiber.
\end{abstract}

Kata Kunci : Kecerdasan emosional, kinerja karyawan, Lingkungan kerja

\begin{abstract}
Abstrack
This study aims to examine the effect of: (1) Emotional intelligence and work environment on employee performance, (2) Emotional intelligence on employee performance, (3) Work environment on employee performance. This study used a causal quantitative research design, the subjects in this study were all employees at CV Bali Coco Fiber Jembrana, the population in this study was 48 employees.Data collected by structured interview techniques and questionnaires. The results of the research on multiple linear regression analysis show that simultaneously.(1) Emotional intelligence has a positive and significant effect on the work environment, (2) Emotional intelligence has a positive and significant effect on employee performance (3) The work environment has a positive and significant effect on employee performance at CV Bali Coco Fiber.
\end{abstract}

Keywords: Emotional intelligence, employee performance, Work environment

\section{Pendahuluan}

Indonesia adalah negara kepulauan dengan menghasilkan buah kelapa terbanyak di dunia. Sejatinya kita bisa menikmati hasil dari nilai tambah buah kelapa yang ternyata tak hanya air dan daging buahnya saja yang bisa dikonsumsi, tetapi dari sabut (coco fiber) dan serbuk kelapa (coco peat) juga memiliki manfaat yang besar. Di daerah yang padat penduduknya, misalnya di Bali dan Jawa. Pemanfaatan limbah berubah sabut kepala masih kurang karena minimnya tingkat kepekaan pendudukan terhadap pengelolaan yang memiliki hasil penjualan yang sangat besar. CV. Bali Coco Fiber merupakan salah satu pabrik serat sabut kepala yang berada di penyaringan/jembrana Bali. Yang kita ketahui bali merupakan penghasil kepala terbanyak di daerah Jembrane dan Tabanan. Perusahan ini adalah penghasil produk setengah jadi yang di ambil dari suplayer dan di proses oleh perusahaan setelah diproses produk dikirim di Surabaya untuk di periksa setelah itu langsung di ekspor ke luar negeri (Cina). Serat sabut kepala di pake sebagai bahan dasar seperti sofa, kasur, spon dan kerajinan lainnya. Serat sabut kelapa setiap harinya akan dikirim/diekspor di luar negeri yaitu dicina setiap minggunya, bali coco fiber memilki 3 cabang yaitu di baluk, penyaringan dan di tabanan. Perusahaan ini memiliki 48 karyawan dan berdiri pada tahun 2015. Serat sabut kelapa sangat menguntukan bagi masyarakat sekitar terutama di Desa penyaringan sehingga dapat dikekola untuk dihasilkan sebagai kerajinan lainnya dan meningkatkan nilai ekonomis yang rendah hingga menjadi ekonomi yang tinggi. Amstrong dan Barong (2008) mengemukakan bahwa kinerja organsasi dipengaruhi oleh empat faktor, yaitu faktor personal, faktor sistem pekerjaan dan fasilitas dan faktor situasional. 
Pada CV. Bali Coco Fiber sebagian besar karyawan belum mampu mencapai standar kinerja yang telah ditetapkan perusahan sehingga masih tergolong rendah untuk mengetahui seberapa tingkat kinerja karyawan, dapat di lihat dari kualitas kerja karyawan yang cukup rendah sehingga menyebabkan karyawan tidak fokus pada kemampuan/ keahlian dan tidak cocok dengan keterampilannya yang dimilikinya.Contohnya terjadinya kesalahan pengemasan serat sabut kelapa karena keahlian yang ditetapkan oleh perusahan terhadap karyawan tidak cocok sehingga sering kali terjadi kerusahan saat pengemasan serat sabut kelapa, sehingga sering terjadi kerugian dan menyebabkan lamanya memproduksi barang untuk di ekspor keluar negri. Belum tercapainya kinerja di perusahan tersebut diduga karena pemanfaatan waktu kerja yang tidak digunakan dengan baik, dan ketepatan waktu kerja yang belum dilaksanakan, karyawan yang sudah melaksanakan isitirahat dengan waktu yang di berikan oleh perusahan sering kali manamba waktu istirahatnya untuk pulang kerumah sehingga memperlambat pekerjaan dan menghambat waktu kerja. Sering kali tidak tepat waktu dalam berkerja sudah menjadi kebiasaan seperti telat datang di waktu pagi hari sehingga memperlambat pekerjaan karyawan dan tidak memiliki kesadaran diri secara individu dalambekerja. permasalahn yang terjadi pada kecerdasan emosional yang ada di perusahan adalah kurangnya komunikasi dan interaksi antara karyawan satu dengan yang lain. Karyawan sangat mementikan pekerjaan dan posisinya di bagian alat produksi serat sabut kepala sehingga lupa untuk menjalin komunikasi yang baik dan berinteraksi terhadap karyawan pada saat bekerja. Kurangnya Motivasi terhadap kinerja, karyawan tidak memiliki perkembangan dan karyawan lebih banyak diam dan tidak memiliki inisiatif untuk bertanya kepada karyawa yang lain, kurangnya semangat dalam melakukan pekerjaan sehingga dapat menyebabkan terjadinya hambatan saat bekerja. Rendahnya kecerdasan emosional akan mempengaruhi kinerja karyawan.

Beberapa permasalahan yang ada di perusahan sesuai dengan indikator yang diterapkan, Yaitu ketidak nyamanan untuk melakukan aktivitas diluar rumah karena debu yang berasal dari asap sabut kelapa. Selanjutnya keamanan yang ada di Perusahan belum di terapkan tidak memiliki penjaga (satpam) dimana itu sangat penting untuk lingkungan sekitar. Kecerdasan emosional pekerja berada pada tingkatan yang rendah dengan nilai jawaban menyeluruh dari pekerja sebesar 129. Hal ini memperlihatkan bahwa tingkat kecerdasan emosional pekerja tergolong rendah. Rendahnya kecerdasan emosional yang dimiliki karyawan disebabkan karena berbagai faktor salah satunya mengenali emosi diri. Rendahnya tingkat pengendalian emosi karyawan akan berdampak pada kinerjanya. Hal ini dipertegas oleh Danang (2010), "tingginya tingkat kecerdasan emosi yang ada pada diri seseorang maka semakin tinggi kinerjanya, kemudian baiknya kemampuan seseorang untuk tetap berfikir realistis dan tidak mengedepankan emosi maka makin besar pula kesadarannya terhadap beban yang harus dilaksanakan oleh pekerja tersebut". Lingkungan kerja menurut Sofyandi, 2008 bahwa lingkungan kerja adalah faktor yang berdampak pada kinerja dari segala aktivitas manajemen yang meliputi faktor-faktor internal yang sumbernya dari dalam organisasi.

Menurut Byars (1984), kinerja didefinisikan sebagai pencapaian pekerja dengan segala pengetahuan dan kesanggupannya dalam melaksanakan segala bentuk beban pekerjaan guna mewujudkan segala hal tersebut pekerja harus memiliki kemampuan dan keahlian. Menurut Moeheriono (2009) kinerja adalah sebuah tampilan terkait segala pencapaian dalam sebuah aktivitas dalam mewujudkan impian perusahaan melalui rencana strategis organisasi. Variabel X1 mempunyai 5 komponen yang dapat berpengaruh terhadap variabel Y (Goleman, 2005:513). Lima hal itu adalah kesadaran diri, pengelolaan diri, dorongan, empati, dan keahlian sosial. Menurut Kinichi dan Kreitner (2008), kecerdasan emosional merupakan kesangguppan seseorang dalam pengelolaan diri dan memiliki hubungan baik dengan seseorang. Rendahnya X1 pada karyawan akan berdampak pada kinerjanya, dapat diketahui dari beberapa indikator yang sudah di terapkan seperti, mengenalisi emosi diri, manajemen diri, motivasi dan keterampilan sosial.

Sedangkan indikator kinerja karyawan menurut (Mathis,2009) adalah Kuantitas dan Kualitas, yang dimana kedua hal tersebut dapat dinilai melalui kehadiran karyawan serta 
melalui hasil kerja yang diselesaikan dan kesempurnaannya. Indikator X2 yaitu: (1) Tempat, pekerja tidak mungkin dapat menyelesaikan segala tugas yang dibebankan terhadapnya dengan baik apabila tempat yang disediakan pihak perusahaan tidak layak dan menimbulkan ketidaknyamanan. Kondisi ruangan yang sempit serta kurangnya fasilitas yang ada akan berdampak terhadap aktivitas pekerja, (2) Peralatan, adanya peralatan yang memadai dan dapat menunjang segala aktivitas dalam bekerja akan menimbulkan kenyamanan bagi para pekerja (3) Proses Kerja (Wirawan, 2008:128).

Dalam penelitian ini terdapat tiga masalah yang teridentifikasi yaitu hambatan waktu dan pemanfaatan waktu terhadap karyawan di perusahaan, suhu udara di ruang kerja yang tidak nyaman dan kurangnya motivasi, ketepatan waktu dalam bekerja kurang maksimal dan hubungan tidak saling percaya antara kinerja karyawan di CV Bali Coco Fiber. Identifikasi permasalah yang terjadi di CV Bali coco fiber adalah sebagai berikut: (1) Kinerja karyawan yang rendah dapat dilihat dari Pemanfaatan waktu yang tidak di gunakan dengan baik.(2) Lingkungan kerja yang tidak nyamanan untuk melakukan aktivitas disebabkan oleh debu ( serat sabut kelapa) dan keamanan yang belum di terapkan oleh CV Bali coco fiber.(3) Kecedasan emosional yang kurang seperti komunikasi dan interaksi para pekerja, sehingga tidak adanya koneksi antara para pekerja yang menimbulkan tingkat motivasinya rendah.

Pengaruh $\mathrm{X}_{1}$ Terhadap $\mathrm{Y}$. Bedasarkan hasil analisis uji regresi maka $\mathrm{X}_{1}$ berpengaruh signifikan terhadap $Y$. Hasil ini memberikan makna bahwa $X_{1}$ berdampak terhadap segala tingkah laku para karyawan dalam mengatasi segala hal. Pegawai yang memiliki kecerdasan emosional yang tinggi dapat menjawab segala permasalahan yang ada dengan sangat baik, sebagai contoh mereka dapat menilai emosi yang muncul dan membuatnya sebagai pengukuran yang baik guna menyelesaikan permasalahan yang ada. Hal ini sejalan dengan pendapat dari ahli Goleman (2007) .

Pengaruh $\mathrm{X}_{2}$ Terhadap $\mathrm{Y}$. Berdasarkan hasil analisis uji regresi maka $\mathrm{X}_{2}$ berpengaruh signifikan terhadap Y. Lingkungan dapat menimbulkan sebuah kerja sama kerja, maka dari itu perusahaan sebagikanya mengupayakan agar kondisi lingkungan kerja lebih menyenangkan karena akan menyebabkan karyawan nyaman dalam bekerja. Lingkungan kerja andil dalam menetapkan buah hasil dari pekerja dalam menggapai tujuan perusahaan.

Pengaruh $X_{1}$ dan $X_{2}$ terhadap $Y$. Variabel $X_{1}$ dan $X_{2}$ secara bersama-sama mempengaruhi kemampuan diri seseorang dalam kinerja karyawan. Dengan adanya kekuatan emosi memperlihatkan akan keberadaan manusia. Kondisi lingkungan yang memadai untuk para karyawan dapat dilihat adanya segala jenis peralatan. kondisi kerja dan lingkungan bekerja yang nyaman akan sangat mempengaruhi pekerja dalam bekerja, pekerja mampu memaksimalkan kinerja guna dapat menggapai tujuan perusahaan yang sebelumnya telah ditetapkan pihak perusahaan ( B, Gani, 2014).

\section{Metode}

Penelitian ini dilakukan untuk memperoleh seberapa besar pengaruh kecerdasan emosional dan Lingkungan kerja terhadap Kinerja Karyawan pada CV. Bali Coco Fiber (Jembrana). Pada penelitian ini terdapat dua variabel bebas yaitu kecerdasan emosional $\left(X_{1}\right)$ dan Lingkungan kerja $\left(\mathrm{X}_{2}\right)$, serta variabel terikat yaitu Kinerja $(\mathrm{Y})$.

Adapun penelitian ini mempergunakan desain kuantitatif kausal sebagai desain penelitian. Penelitian kausal merupakan suatu penelitian guna pemperoleh sebuah hubungan (Sugiyono, 2014). Desain penelitian ini merupakan desain penelitian kausal yang memiliki beberapa tahapan. 
Tabel 4.1

Data Karakteristik Responden

\begin{tabular}{llll}
\hline Deskriptif & Keterangan & Frekuensi & \\
& & & \\
\hline Jenis & Laki-Laki & 25 & 52 \\
Kelamin & Perempuan & 23 & 48 \\
& & & \\
& Jumlah & 48 & 100 \\
Umur & 25-30tahun & 26 & 54 \\
& 31-40tahun & 14 & 29 \\
& 41-50tahun & 8 & 17 \\
& Jumlah & 48 & 100 \\
\hline
\end{tabular}

Berdasarkan data pada tabel 4.1, dapat dilihat bahwa responden yang terdapat pada penelitian ini adalah responden laki-laki sebanyak 25 orang atau sebesar $52 \%$ dan responden perempuan sebanyak 23 orang atau sebesar $48 \%$. Hal tersebut memperlihatkan sebagian besar responden adalah laki-laki. Apabila melihat dari segi lainnya yaitu usia, lebih banyak yang berumur sekitaran 25-30 tahun sedangkan sejumlah 26 orang atau sekitar $54 \%$, yang berumur kurang lebih 31-40 tahun yaitu sejumlah 14 orang atau sekitar $29 \%$ dan berumur 41-50 tahun sejumah 8.

Subjek dari ini adalah karyawan CV. Bali Coco Fiber dan objekk dalam penelitian ini adalah kecerdasan emosional dan lingkungan kerja, dan kinerja. Penelitian ini merupakan penelitian populasi. Hal ini berarti seluruh populasi pada penelitian ini digunakan untuk diteliti. keseluruhan pekerja di CV. Bali Coco Fiber dengan jumlah 48 orang merupakan populasi dalam penelitian ini.

Sebuah kuesioner dinyatakan sah apabila pertanyaan pada kuesioner tersebut mampu menjawab sesuatu yang akan dinilai kuesioner tersebut. Instrumen penelitian dinyatakan sah jika adanya hubungan antara tiap faktor tersebut searah dan bernilai $>$ dari tabel yang terkait. Menurut Sugiyono (2004) sebuah instrumen dinyatakan valid jika koefisien korelasi antar butir > dari 0,30 dengan tingkat kesalahan alpha 0,05. Pengolahan data untuk menilai validitas butir kuesioner tersebut ditolong oleh sebuah program Statistical Package for Social Sience (SPSS) 24.0 forWindows.

sebuah kuesioner dinyatakan andal apabila keseluruhan jawaban yang diberikan responden terkait segala pertanyaan yang tercantum pada kuesioner tersebut adalah konsisten atau stabil dari waktu ke waktu. Kriteria suatu instrument penelitian dapat dinyatakan andal dengan teknik ini, jika reliabilitas $\left(r_{i}\right)>0,60$. Pengolahan data untuk melihat keandalan sebuah kuesionar pada penelitian ini ditolong dengan program Statistical Package for Social Sience (SPSS) 24.0 for Windows, hal ini dapat mempermudah peneliti untuk melihat keandalan dari sebuah kuesioner.

Sebelum dilaksanakannya sebuah analisis regresi linear berganda, terlebih dahulu dilakukan uji asumsi klasik, yaitu uji normalitas, uji multikolinearitas, dan uji heteroskedastisitas. Penggunaan ini memiliki tujuan guna untuk menilai seberapa layak uji tersebut, dan akhirnya akan dipergunakan untuk menganalisis terlepas dari adanya kesimpangan uji tersebut. Uji ini memiliki tujuan untuk memperoleh informasi mengenai ada tidaknya hubungan antara variabel bebas yang satu dengan variabel yang lainnya.

Untuk mendekati adanya multikolinearitas dapat dilihat dari nilai Variance Inflation Factor (VIF) dan nilai Tolerance. Tolerance mengukur variabilitas variabel bebas yang terpilih yang tidak dapat dijelaskan oleh variabel lainnya. Jadi, nilai tolerance rendah sama dengan nilai $\mathrm{VIF}$ tinggi (karena $\mathrm{VIF}=1 /$ tolerance) dan memperlihatkan adanya kolinearitas yang tinggi. Berdasarkan aturan Variance Inflation Factor (VIF) dan tolerance, maka apabila VIF melebihi angka 10 atau tolerance kurang dari 0,10 maka dinyatakan terjadi gejala multikolinearitas. Sebaiknya apabila nilai VIF kurang dari 10 atau tolerance lebih dari 0,10 maka dinyatakan tidak terjadi gejala multikolinearitas. Ringkasan hasil uji multikolinearitas 
disajikan pada table 4.2 berikut.

Tabel 4.2

Ringkasan Hasil Uji Multikolinearitas

\begin{tabular}{llll}
\hline Model & $\begin{array}{l}\text { Collinearity } \\
\text { Statistics } \\
\text { Tolerance }\end{array}$ & VIF & Keterangan \\
\hline $\begin{array}{l}\text { Kecerdasan } \\
\text { Emosional }\end{array}$ & 0,758 & 1,319 & $\begin{array}{l}\text { Mebas } \\
\text { Multikolinearitas }\end{array}$ \\
Lingkungan Kerja & 0,758 & 1,319 & $\begin{array}{l}\text { Bebas } \\
\text { Multikolinearitas }\end{array}$ \\
\hline
\end{tabular}

Berdasarkan data padatabel 4.2 dapat dilihat bahwa keseluruhan variabel bebas memiliki sebuah nilai VIF < dari 10 dan nilai tolerance $>$ dari 0,10 , sehingga model penelitian ini terbebas dari uji multikolinearitas.

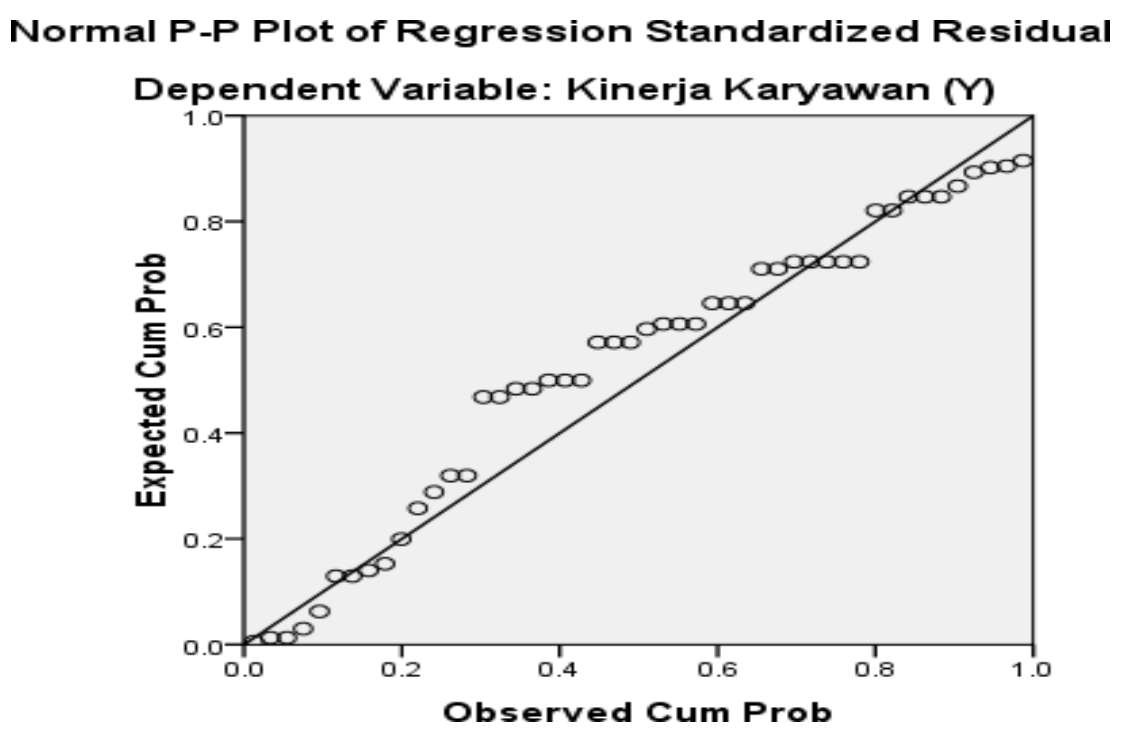

Gambar 4.1

Grafik Normal P-P Plot of Regression Stadardized Residual

Dari hasil analisis grafik tersebut maka dapat dipastikan bahwa data pada penelitian ini memiliki distribusi yang baik karena datanya berada pada sekitaran garis diagonal dan mengikuti arah garis diagonal, maka dapat dikatakan bahwa model regresi memenuhi asumsi normalitas. Uji Multikolinearitas uji ini memiliki tujuan guna memperoleh informasi terkait ada tidaknya hubungan antara variabel independen yang satu dengan variabel yang lainnya. Untuk mendekati adanya multikolinearitas dapat dilihat dari nilai Variance Inflation Factor (VIF) dan nilai Tolerance. Berdasarkan aturan Variance Inflation Factor (VIF) dan tolerance, maka apabila VIF melebihi angka 10 atau tolerance kurang dari 0,10 maka dinyatakan adanya gejala multikolinearitas, begitupula sebaliknya. 


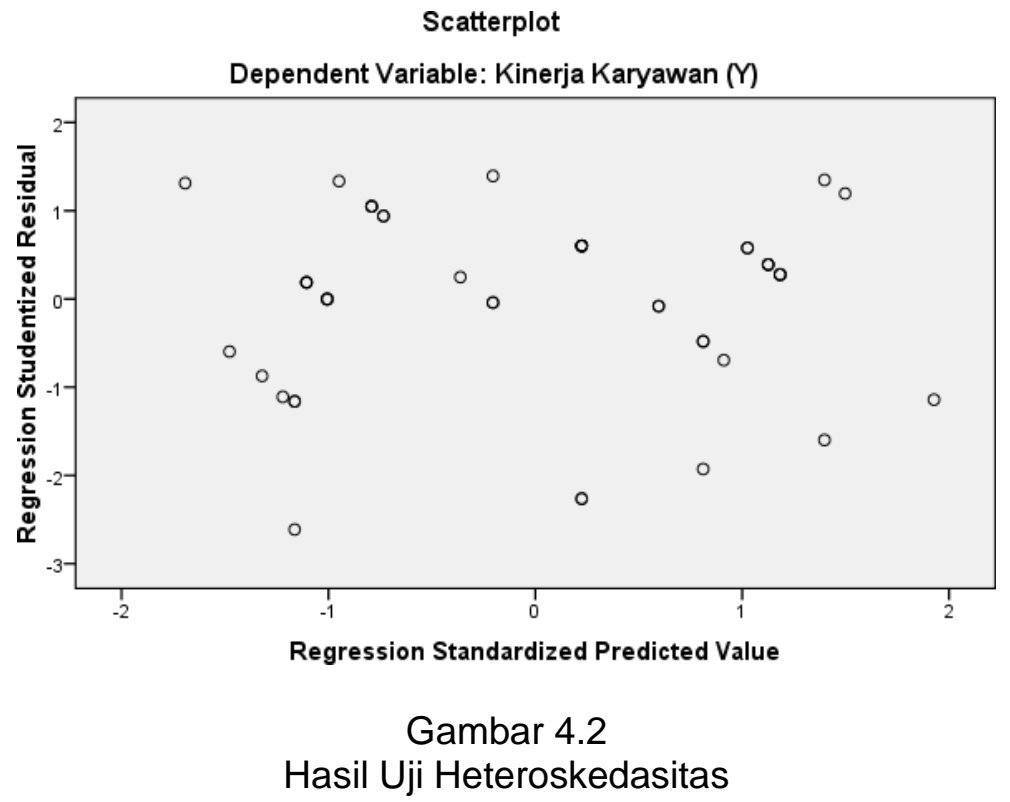

Dapat dilihat dari gambar diatas bahwa titik-titik berada diatas dan dibawah angka 0 pada sumbu $Y$, yang artinya dalam penelitian ini tidak terjadi heteroskedasitas. Data pada penelitian memiliki distribusi yang normal, sehingga tidak ditemukannya gejala multikolinearitas dan tidak ditemukan gejala heteroskedastisitas maka data dinyatakan memenuhi uji asumsi sehingga dapat dilakukan pengujian hipotesis.

\section{Hasil Dan Pembahasan}

Pengujian hipotesis dilakukan dengan mempergunakan model regresi berganda. Model regresi berganda dipergunakan guna memperoleh jawaban terkait rumusan masalah yang ada pada penelitian ini, yaitu guna melihat pengaruh antara dua variabel atau lebih. Kinerja Karyawan merupakan variabel terikat dalam penelitian ini, sedangkan variabel diantaranya: Kecerdasan Emosional dan Lingkungan Kerja. Hasil analisis regresi berganda disajikan pada tabel 4.3 berikut:

Tabel 4.3

Rekapitulasi Hasil Analisis Regresi Linear Berganda

\begin{tabular}{|c|c|c|c|c|c|}
\hline \multirow[t]{2}{*}{ Model } & \multicolumn{2}{|c|}{$\begin{array}{l}\text { Unstandardized } \\
\text { Coefficients }\end{array}$} & \multirow{2}{*}{$\begin{array}{l}\text { Standar } \\
\text { dized } \\
\text { Coeffici } \\
\text { ents } \\
\text { Beta }\end{array}$} & \multirow[t]{2}{*}{$T$} & \multirow[t]{2}{*}{ Sig. } \\
\hline & $B$ & $\begin{array}{l}\text { Std. } \\
\text { Error }\end{array}$ & & & \\
\hline (Constant) & 4,162 & 1,206 & & 3,449 & 0,001 \\
\hline $\begin{array}{l}\text { Kecerdasan } \\
\text { Emosional }\end{array}$ & 0,275 & 0,067 & 0,334 & 4,103 & 0,000 \\
\hline $\begin{array}{l}\text { Lingkungan } \\
\text { Kerja }\end{array}$ & 0,477 & 0,058 & 0,666 & 8,191 & 0,000 \\
\hline
\end{tabular}

Berdasarkan perhitungan regresi linear berganda pada tabel 4.3, maka didapatkan hasil persamaan regresi sebagai berikut: Konstanta 4,162 memperlihatkan bahwa jika variabel Kecerdasan Emosional, Lingkungan Kerja dan Jaminan Kredit bernilai konstan, maka rata- 
rata nilai variabel Kinerja Karyawan adalah sebesar 4,162. Koefisien regresi Kecerdasan Emosional sebesar 0,275 berarti bahwa apabila terdapat penambahan Kecerdasan Emosional sebesar 1 satuan, maka Kinerja Karyawan akan meningkat sebesar 0,275 satuan.

Koefisien regresi Lingkungan Kerja sebesar 0,477 berarti bahwa apabila terdapat penambahan Lingkungan Kerja sebesar 1 satuan, maka Kinerja Karyawan akan meningkat sebesar 0,477 satuan.

Kuesioner adalah sebuah strategi yang dipergunakan untuk memperoleh data yang dilaksanakan dengan teknik mengajukan sebuah pertanyaan tertulis terhadap responden yang nantinya akan dijawab oleh mereka. Kuesioner diberikan kepada responden dengan cara: (1) memberikan kuesioner, (2) responden diminta untuk menjawab pada lembar jawaban yang ada, (3) lembar kuesioner yang telah dijawab kemudian dikumpulkan, diolah, dan dianalisis jawaban tersebut ditentukan skornya beruba skala ordinal. Wawancara terstruktur. Wawancara ini dilakukan selama observasi awal dengan pihak pemilik perusahaan itu sendiri, bagian manager serta karyawan pada CV Coco Fiber.

Pwngujian Uji t dilakukan untuk memperlihatkan sejauh mana pengaruh variabel behas terhadap variabel terikat dengan menganggap variabel lainnya konstan. Kemudian menetapkan hipotesis diterima atau ditolak pada penelitian ini yaitu dengan melihat nilai signifikansi dengan kriteria sebagai berikut:

Apabila nilai signifikansi $>0,05$, maka Hipotesis ditolak yang memiliki arti bahwa variabel $X$ tidak berdampak pada variabel $Y$. Jika jumlah signifikansi $<0,05$, maka Hipotesis diterima yang artinya variabel $\mathrm{X}$ berdampak pada variabel $\mathrm{Y}$. Berdasarkan hasil uji statistik $\mathrm{t}$ dikatakan: Pengujian hipotesis pertama $\left(H_{1}\right)$ bahwa $X 1$ sebesar $0,000<0,05$, maka dapat dinyatakan bahwa Kecerdasan Emosional berdampak terhadap kinerja. Nilai t positif memperlihatkan bahwa variabel $X_{1}$ mempunyai hubungan yang searah dengan $Y$. Jadi dapat disimpulkan bahwa $\mathbf{H}_{\mathbf{1}}$ diterima yaitu Kecerdasan Emosional berpengaruh positif dan signifikan terhadap Kinerja Karyawan.Pengujian hipotesis kedua $\left(\mathrm{H}_{2}\right)$ dapat dilihat pada tabel 4.6 bahwa nilai signifikansi Lingkungan Kerja sebesar 0,000 $<0,05$, maka dapat dinyatakan bahwa variabel $\mathrm{X}_{2}$ mempunyai pengaruh terhadap $\mathrm{Y}$. Nilai t positif menunjukkan bahwa variabel $X_{2}$ mempunyai hubungan yang searahdengan.

Jadi dapat disimpulkan bahwa $\mathbf{H}_{\mathbf{2}}$ diterima yaitu Lingkungan Kerja berpengaruh positif dan signifikan terhadap Kinerja Karyawan. Nilai konstanta sebesar 4,162 menunjukan bahwa jika variabel Kecerdasan Emosional, Lingkungan Kerja dan Jaminan Kredit bernilai konstan, maka rata-rata nilai variabel Kinerja Karyawan adalah sebesar 4,162. Koefisien regresi Kecerdasan Emosional sebesar 0,275 berarti bahwa apabila terdapat penambahan Kecerdasan Emosional sebesar 1 satuan, maka Kinerja Karyawan akan meningkat sebesar 0,275 satuan.Koefisien regresi Lingkungan Kerja sebesar 0,477 berarti bahwa apabila terdapat penambahan Lingkungan Kerja sebesar 1 satuan, maka Kinerja Karyawan akan meningkat sebesar 0,477 satuan.

\section{Simpulan Dan Saran}

Berdasarkan hasil pengujian statistik dan hipotesi serta pembahasan yang telah dilakukan dapat ditarik simpulan sebagai berikut. X1 dan $\mathrm{x} 2$ berdampak secara signifikan terhadap Y di Cv. Bali coco fiber jembrana. X1 berpengaruh positif dan signifikan terhadap Y di CV. Bali Coco Fiber Jembrana. X2 berpengaruh positif dan signifikan terhadap Y CV. Bali Coco Fiber Jembrana.

Bagi pengelolah CV. Coco Fiber Jembrana lebih memperhatikan atau meningkatkan lagi komunikasi dan interaksi antar pekerja agar dapat berinteraksi dengan jelas penelitian ini telah dijelaskan bahwa kecerdasan emosional dan lingkungan kerja sama-sama bertujuan untuk meningkatkan semangat kerja dan kemampuan karyawan sehingga terciptanya karyawan yang maksimal. Bagi penelitian selanjutnya dapat mengembangkan komunikasi yang luas dan interaksi terkait variabel dalam penelitian ini.

Terhadap karyawan, kinerja karyawan, dapat di lihat dari kualitas kerjakaryawan

yang cukup rendah sehingga menyebabkan karyawan tidak fokus pada kemampuan/keahlian dan tidak cocok dengan keterampilannya yang dimilikinya. 


\section{Daftar Pustaka}

Agustian, Ary Ginanjar. 2003. ESQ POWER Sebuah Inner Journey Melalui Al Ihsan. Jakarta: Arga.

Dessler, Garry.2000. Manajemen personalia.Jakarta: Erlangga

Daulay, Muhamad Toyib. 2009. Pengaruh Kecerdasan Emosional Terhadap Produktivitas Karyawan Pada PT.Sinar Inti Berkah Sejahtera Medan. Jurnal IImiah Abdi IImu. Vol. 2, No. 1, Hal. $107-119$.

Goleman, D. 2009. Kecerdasan Emosional : Mengapa El lebih penting dari pada IQ. Terjemahan: Hermaya, T. Jakarta: Gramedia Pustaka Utama.

Goleman, Daniel , 2005. Working With Emotional Intelligence. Terjemah Alex Tri Kantjono W. Jakarta.

Goleman, D. 2009. Kecerdasan Emosional : Mengapa EI lebih penting dari pada IQ. Terjemahan: Hermaya, T. Jakarta: Gramedia Pustaka Utama.

Herman sofyandi , 2008. Manajemen sumber daya manusia, edisi pertama . penerbitan graha ilmu, Yogyakarta.

Kreitner dan kinicki, (2008). Organisation behaviour, five edition, new jersey pearsen Education.

Moeheriono, 2009 pengukuran Kinerja Berbasis Kompetenai Bogor : Ghalih.

Mangkunegara, Anwar Prabu, 2012, Evaluasi Kinerja SDM, Refika Aditama,Bandung.

Mathis, Robert. L dan Jackson, jhon. H (2009). Human Resource Management. Jakarta: Salemba Empat.

Nitisemito, Alex S. 2006. Manajemen Personalia.Ghalia Indonesia,Jakarta.

Prihutami, Nurul Dwi, dkk. 2015. "Strategi Human Capital Group Department dalam Mengembangkan Keterikatan Karyawan (Employee Engagement) (Studi Kasus: Unit Operasional PT Bumitama Gunajaya Agro)". Jurnal Aplikasi Manajemen (JAM), Vol. 13, No. 4.

Subiyanto, B. dkk. 2003. Pemanfaatan Serbuk Kelapa Sebagai BahanPenyerap Air dan Oli Berupa Panel Papan Partikel. Journal of Tropical Wood Science and Technology 1:26-34,

Sudarsono, Rusianto, T., dan Suryadi, Y., 2010.Pembuatan Papan Partikel Berbahan Baku Sabut Kelapa Dengan Bahan Pengikat Alami (Lem Kopal).Jurnal Teknologi Akprind.Sedarmayanti. 2007. Manajemen sumber daya manusia reformasi birokrasi dan Manajemen pegawai

Sutrisno, E. 2009.Manajemen sumber daya manusia.Jakarta : Kencana. Negeri sipil.Bandung PT. Refika Aditama.

Sedarmayanti. 2007Manajemen sumberdaya manusia reformasi birokrasi dan manajemen pegawai negeri sipil. Bandung PT Refika Aditama.

Sugiyono. 2004. Metode Penelitian Bisnis. Bnadung:CV Alfabeta. 
Wirawan (2008), Budaya dan iklim organisasi Jakarta: Salemba Empat. 